\title{
II \\ RESEARCH ON INTERNAL CONTROL INFORMATION DISCLOSURE OF LISTED COMPANIES
}

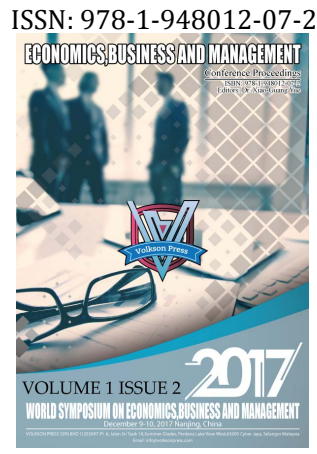

\author{
Yu Shi \\ Business School of Huaiyin Institute of Technology, Jiangsu Province, China. \\ *Corresponding Author Email: shiyu1971@163.com
}

This is an open access article distributed under the Creative Commons Attribution License, which permits unrestricted use, distribution, and reproduction in any medium, provided the original work is properly cited.

\section{ARTICLE DETAILS}

\section{ARTICLE HISTORY:}

Received 27th December 2017

Accepted 29th December 2017

Available online 29th December 2017

\section{ABSTRACT}

This paper focuses on the external social environment and the internal environment of listed companies in China, points out the problems existing in the internal control information disclosure of listed companies in China, analyzes the causes and puts forward strategies and solutions to solve the problems.

\section{KEYWORDS:}

listed companies, internal control

information disclosure, countermeasures

\section{INTRODUCTION}

With the reform and opening up, the economy of China has developed rapidly, and listed companies in China grow gradually, which makes people happy [1]. But at the same time, it should be noticed the potential problems: the listed companies in China started late. A lot of relevant information disclosure systems of internal control basic framework have only some rough basic structures and lack concrete preparedness and response measures [2]. Therefore, based on the research results of experts at home and abroad, it is of great significance to study the loopholes and solutions of the internal control information disclosure of Listed Companies in China.

\section{THE PROBLEMS OF INTERNAL CONTROL INFORMATION DISCLOSURE OF LISTED COMPANIES IN CHINA}

2.1 Lack of cognition of internal control information disclosure of listed companies

According to the current situation, China has not built a relatively mature internal control standardization system (such as the United States COSO authority), there is no relatively consistent indicators. Most of the relevant laws and regulations only provide a general framework, which leads to the framework that the listed companies can make use of their loopholes and disclose only basic requirements [3]. Under such circumstances, the quality of the internal control information disclosure of listed companies will inevitably be affected, and the normal operation of the economic market will be hindered.

2.2 Internal control information disclosure of listed companies lacks of relevant unified standards

According to the current situation, China has not built a relatively mature internal control standardization system (such as the United States COSO authority), there is no relatively consistent indicators. Most of the relevant laws and regulations only provide a general framework, which leads to the framework that the listed companies can make use of their loopholes and disclose only basic requirements. Under such circumstances, the quality of the internal control information disclosure of listed companies will inevitably be affected, and the normal operation of the economic market will be hindered.

2.3 The internal control information disclosure of listed
companies is not timely

The asymmetry of information is one of the characteristics of the theory of internal control information disclosure. Because the management of Listed Companies in the management of the company is in constant development, which means not immutable. The management of the company is often the first to receive information while the relevant interests of investors often do not know some latest news [4]. Therefore, some companies will take advantage of this, intentionally or unintentionally delay the time of information disclosure, which leads to insider trading and indirect manipulation of stock price.

\subsection{CPA audit opinions and independence problems}

The audit results of listed companies will be directly affected by the negative attitude of certified public accountants. This type of CPA does not take the overall development of listed companies as a consideration but only to complete some financial related indicators tasks, and finally makes it difficult to issue substantive audit opinions. Therefore, the lack of authenticity of the internal control report of CPA's audit opinion leads to a general decline in the reliability of financial reporting. In addition, there will be price competition between accounting firms, and some accounting firms will be responsible for auditing and consulting for many enterprises at the same time, so the independence of audit is also questionable.

\section{THE ANALYSIS OF PROBLEMS OF INTERNAL CONTROL INFORMATION DISCLOSURE OF LISTED COMPANIES}

3.1 The internal control information disclosure of listed companies has not been fully concerned by investors

Demand and supply are mutually determined and interacted. Through the principle of economics, we can correctly understand the relationship between investors and listed companies. The investor is the 
information demand side, if investors cannot pay enough attention to internal control information disclosure, the listed companies as supply side will become difficult to have the motivation to disclose information.

3.2 The disclosure of internal control information of listed companies is restricted by cost budget

To maximize the economic benefits is the main purpose of each enterprise, but the conflict is that the disclosure of internal control information is bound to produce cost, which includes the manpower cost, test data and information recording cost, finishing the CPA's audit fees etc Therefore, the managers of listed companies are more willing to disclose the internal control information which only pays attention to the form and ignores the substance when taking these factors into consideration.

\subsection{The internal governance structure design of listed companies is unreasonable}

Different from the listed companies in other countries, most of the members of Listed Companies in China are state-owned enterprises, restructured state-owned enterprises and family enterprises. These companies often have the same feature: the owner's absence. In this case, large shareholders often ignore the interests of small and medium-sized shareholders, leading to the result that small shareholders are difficult to exercise their rights. That's why most small and medium shareholders focus on the short-term interests of the company and no longer pay attention to the long-term interests of the company. In the long run, the internal control is getting less powerful, so it cannot guarantee the quality of the disclosure of the internal control information.

3.4 The supervision department of our country is weak and lack of effective legal protection at this stage

Because of the unique characteristics of economic market, if there is lack of effective supervision measures, the corruption will inevitably rise. At present our country has not set up mature and relevant laws and regulations of the disclosure of internal control information of listed companies, which leads directly to the consequence that listed company managers and the CPA who is responsible for the auditing of internal control are not clearly definited. Even though it is able to definite clearly, there is no relevant punishment. Therefore, some listed companies tend to miss some information of the disclosure of internal control and carry on with things carelessly.

Disclosure of internal control information may disclose trade secrets

The kinds of disclosure of internal control information of most listed companies are roughly the same and because of this, if a company wants to show itself from many investors eyes, it would have to disclose internal control information with more details, but the contradiction is that the more detailed information is disclosed, the more it's related to the company's trade secrets. If a listed company's trade secrets are well known by competitors, there will be a great disadvantage negotiation. In view of these factors, although the CSRC requires listed companies to disclose detailed internal control information, many listed companies are still only disclosed in accordance with the minimum standards.

\section{COUNTERMEASURES TO SOLVE THE PROBLEMS OF DISCLOSING INTERNAL CONTROL INFORMATION OF LISTED COMPANIES}

4.1 The manager of the company should enhance the understanding of the importance of the disclosure of internal control information

Company managers can use these methods to enhance the understanding of disclosure of internal control information:

First, build a proactive internal control environment. Enterprises should regularly train managers and staff to form an enterprise culture atmosphere which emphasizes internal control, so as to strengthen the disclosure of internal control information.

Secondly, the relevant government departments should spare no efforts to popularize the knowledge of policies and regulations to the managers of the company.

\subsection{Improve the governance structure of listed companies}

There are several ways to optimize the governance structure of listed companies. The first is to improve the ownership structure. Listed companies can reallocate the internal equity, so that small and mediumsized shareholders can hold more equity. The second is to improve the independence of the director system. That is to allow directors to analyze and determine some of the important projects independently in the enterprise, so that there can be enough objectivity in work. The third is to improve the system of supervisors, allowing the members of the board of supervisors to hold a small amount of equity.

\subsection{Improve the laws and regulations system related to internal} control information disclosure

Perfect the relevant legal system of internal control information disclosure. First of all, the standard system of information disclosure should be unified. The regulatory authorities need to fully understand the coverage of each regulation and regulation. Secondly, establish the responsibility body of information disclosure. The main body of responsibility of listed companies is usually divided into two parts: the internal responsibility body and the external responsibility body. The internal responsibility body refers to the board of directors, the board of supervisors and the internal audit committee, etc. while the main body of external responsibility is composed of certified public accountants. Finally, severe punishment should be given to those who violate the regulations.

4.4 Improve the flexibility of internal control design of listed companies and the standardization of information disclosure

Because the operating characteristics, corporate culture, business processes of listed companies are different, the same internal control system is not matched in many enterprises, even the company internal control systems used in one company in different periods are not necessarily the same. Therefore, it is very important to enhance the diversity of internal control system, which requires enterprises to take into account the actual situation to establish the internal control system. Another is that it needs to make the internal control evaluation highly scientific, persistent and timely. At the same time, there must be standard in the disclosure of information.

\subsection{Enhance the professional ethics and professional level of Certified Public Accountants}

The CPAs are responsible for the social control of the internal control system of listed companies, whose main job is to review and verify the information disclosure reports of listed companies and to put forward the auditing opinions. The specificity of profession requires CPAs must have good professional ethics and professional level. On one hand, the work of CPAs must be based on objective and fair working attitude. On the other hand, CPAs should constantly improve their own practice level, regularly attend the internal control knowledge lectures organized by the nation, actively participate in the internal control audit skills training conducted by the accounting firms and enhance the team cooperation ability.

\section{REFERENCE}

[1] Ragahunandan, K., Rama, D.V. 1994. Management reports after COCO [J]. Internal Auditor.

[2] Hou, X., Lu, S. 2016. The problèmes of information disclosure of listed companies and improving measures [J]. Business accounting, 1 (08).

[3] Zhang, Y. 2016. Analysis of the problems and suggestions of internal control information disclosure of Listed Companies in China [J]. Shanxi finance and taxation, 5 (09).

[4] Feng, T. 2016. Research on internal control information disclosure of Listed Companies in China [J]. Finance and economics circles (Academic Edition), 4 (19). 